\title{
Population Dynamic of Phenacoccus solenopsis Tinsley on Cotton Plants and Its Susceptibility to Some Insecticides in Relation to the Exposure Method
}

\author{
El-Zahi Saber El-Zahi ${ }^{1 *}$, Abd-Elsalam Ismail Farag ${ }^{1}$
}

\begin{abstract}
The cotton mealybug, Phenacoccus solenopsis Tinsley (Hemiptera: Pseudococcidae) was first recorded during 2014 as an invasive cotton pest in Egypt. Thus, field experiments were conducted during the seasons 2015 and 2016 to study the population dynamic of $P$. solenopsis on cotton in Kafr El-Sheikh governorate, Egypt. Also, chlorpyrifos, methomyl, deltamethrin, lufenuron, acetamiprid, thiamethoxam and imidacloprid were tested for their toxicity to the third instar nymphs of $P$. solenopsis under laboratory conditions using leaf-dip and insect-spray methods. In both seasons, the infestation of $P$. solenopsis started during the early June when the cotton plants aged about two months. The highest population densities of 142.9 \pm 15.6 and $191.5 \pm 18.1$ insects per twig were recorded on September $6^{\text {th }} 2015$ and September $11^{\text {th }} 2016$, respectively. The infestation was positively correlated with the maximum $(r=0.77)$ and minimum $(r=0.71)$ temperature and the relative humidity $(r=0.49)$. Based on the multiple regression analysis and the coefficient of determination values $\left(R^{2}\right)$, the maximum and minimum temperature and the relative humidity were responsible for the changes in the insect population by $54.2-63.7 \%$. Thiamethoxam was the most effective insecticide $\left(\mathrm{LC}_{50}=\right.$ 23.6 $\mathrm{mg} \mathrm{AI} \mathrm{L}^{-1}$ ) against the third instar nymphs of $P$. solenopsis using the leaf-dip method, while lufenuron was the least toxic one with $L_{50}$ value of $556.1 \mathrm{mg} \mathrm{AI} \mathrm{L}^{-1}$. When the insect-spray method was adopted, the toxicity of deltamethrin and lufenuron increased, whereas the toxicity of the others decreased comparing to that obtained in the leaf-dip method.
\end{abstract}

Key words: Phenacoccus solenopsis, cotton, population dynamic, weather factors, insecticides, exposure method.

\section{INTRODUCTION}

The cotton mealybug, Phenacoccus solenopsis Tinsley is a highly polyphagous sap sucking insect, native to USA (Fuchs et al., 1991), and later spread over a wide range of tropical and subtropical countries. Cotton is considered of the most preferred hosts of $P$. solenopsis (Abbas et al., 2010). This solenopsis mealybug not only causes direct damages to cotton plants by sucking the cell sap, but also excretes large quantities of honey dew which encourages the black sooty mold growth and hinders the photosynthesis process (Arif et al., 2012). Besides this, ants feed on the sugary honey dew, playing a very serious role in the spread of mealybug infestation and deter biological control agents (Cudjoe et al., 1993). The infested cotton plants become stunted, weak and fruit a few small bolls resulting in severe economic yield losses (Dhawan et al., 2007; El-Zahi et al., 2016). In Egypt, P. solenopsis was first recorded in 2014 as a new invasive pest attacking the cotton plantations (El-Zahi et al., 2016), and it is predicted to become one of the most dangerous cotton pests within the next few years, where the agroecosystem is closely adequate to its development and spread. This insect has a high reproductive potential in wide ranges of temperature (Prasad et al., 2012) and relative humidity (Hameed et al., 2012), and a waxy secretion on the body surface that protect it from insecticides and natural mortality factors. The cotton growers mostly rely on insecticides to control the insects infesting their crops because the insecticides act rapidly on the infestation, less cost and easily applied (Rashid et al., 2011). Phenacoccus solenopsis infestations on different hosts could be effectively controlled using biological control agents, plant extracts, mineral oils and synthetic insecticides (Aheer et al., 2009; Suresh et al., 2010; Kumar et al., 2012; El-Zahi et al., 2016). The information about the biological activities of $P$. solenopsis in the cotton fields under the Egyptian condition is not available till now, and no insecticides are recommended to its control as well. Thus, the present investigations were planned to study the population dynamic, seasonal abundance and peak activity of $P$. solenopsis on cotton, and to determine its susceptibility to some synthetic insecticides using leafdip and insect-spray methods under laboratory conditions.

\section{MATERIALS AND METHODS}

\section{Insecticides}

Commercial formulations of lufenuron (Match 5\% EC, Syngenta Agrosciences, Switzerland), chlorpyrifos (Dursban H 48\% EC, Dow Agrosciences, UK), methomyl (Neomyl 90\% SP, Rotam Agrochemical Co. Ltd., Hong Kong), deltamethrin (Decis 2.5\% EC, Bayer Crop Science, Germany), acetamiprid (Newcet 20\% SP, Jinan Leader Chemical Co. Ltd., China), thiamethoxam (Actara 25\% WG, Syngenta Agrosciences, Switzerland) and imidacloprid (Ecomida 30.5\% SC, Bharat

\footnotetext{
${ }^{1}$ Plant Protection Research Institute, Agricultural Research Center, Dokki, Giza, Egypt.

*Corresponding address: zasaber951@yahoo.com

Received May 1, 2017, Accepted May 31, 2017
} 
Insecticides Ltd., India) were tested for their toxicity to $P$. solenopsis under laboratory conditions.

\section{Insect colony establishment}

To establish a culture of $P$. solenopsis, infested cotton twigs were collected from unsprayed fields and brought to the laboratory. Adult females were separated and inoculated on cotton plants of two months age, potted under laboratory conditions of $30 \pm 2^{\circ} \mathrm{C}, 65 \pm 5 \mathrm{RH}$ and 13:11(L: D) photoperiod. Two days later, the females settled on plant leaves and stems and started egg laying. The newly moulted third instar nymphs were used in the laboratory experiments.

\section{Field experiments}

The survey for $P$. solenopsis infestations on cotton plants (Gossypium barbadense var. Giza 92) was conducted at the farm of Sakha Agricultural Research Station, Kafr El-Sheikh governorate, Egypt during the cotton growing seasons 2015 and 2016 in an area of approximately $2000 \mathrm{~m}^{2}$. This area did not receive any insecticidal treatments during the two seasons. The survey started one month after plant emergence and continued till harvesting at fortnightly observations. In each observation, 100 apical twigs of the same age were randomly chosen from this area (20 twigs from each corner plus 20 from the center) to count the adult females and third instar nymphs of the mealybug. The mean population per twig was calculated and correlated with the weather factors: maximum temperature, minimum temperature and relative humidity which were obtained from the Meteorological Station of Sakha, Egypt.

\section{Laboratory experiments}

\section{Leaf-dip method}

A serial of concentrations was prepared from each insecticide using tap water for dilutions. Fresh cotton leaves with petioles were washed thoroughly with tap water and shad dried. Ten leaves were dipped in each concentration for 20 seconds and in the tap water only for the control, and then shade dried. Circular openings were created in nine $\mathrm{cm}$ diameter plastic Petri dishes. The treated leaves were placed individually inside the dishes, while their petioles passed through the openings and immersed in $1 \%$ sucrose solution to keep the leaves alive (Fig. 1). A filter paper was put underneath each leaf to absorb any water vapor. Twenty newly moulted third instar nymphs of $P$. solenopsis were transferred to each Petri dish using a fine camel hair brush, representing one replication. Ten replications were made for each concentration and the control. The dishes were covered with their lids to prevent the insect escape, and maintained under constant conditions of $30 \pm 2{ }^{\circ} \mathrm{C}, 65 \pm 5$ RH and 13:11(L: D) photoperiod. A binocular microscope was used to distinguish dead insects from live ones. Number of dead insects and the percentages of mortality were recorded after $72 \mathrm{~h}$ of the treatment. In the case of the chitin synthesis inhibitor (lufenuron) the data were recorded after 6 days of the treatment. Where, the third instar nymphs of $P$. solenopsis moult to the next stage after $5.20 \pm 0.45$ days (Prishanthini and Vinobaba, 2013).

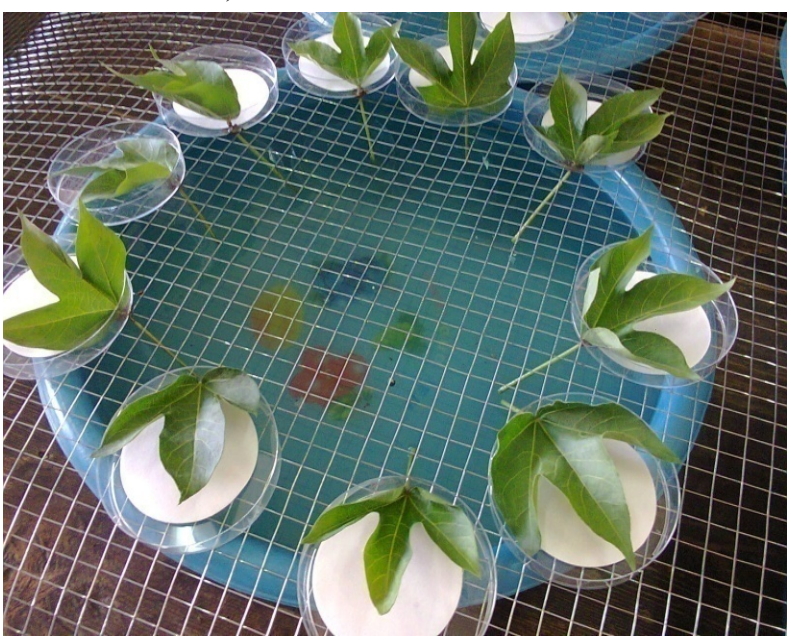

Fig.1. Preparing of Petri dishes: Seen are the petioles of the cotton leaves passed through the openings and were immersed in $1 \%$ sucrose solution to keep the leaves alive for about a month

\section{Insect- spray method}

Adult females of $P$. solenopsis were transferred to cotton plants of two months age. When the offspring emerged to the $3^{\text {rd }}$ instar nymphs, the cotton plants were closely sprayed with $15 \mathrm{ml}$ insecticide solution per plant. Each concentration was applied to five plants using a hand sprayer. The concentrations of the test insecticides and the Petri dishes were prepared as previously described. Untreated cotton leaves were placed in all the Petri dishes. After complete dryness of the sprayed plants, 20 newly moulted third instar nymphs of $P$. solenopsis were transferred to each Petri dish with aid of a fine camel hair brush, representing one replication. For the control, the nymphs were transferred from plants sprayed with water only. Ten replications were made for each concentration and the control. The dishes were covered with their lids to prevent the insect escape, and maintained under constant conditions of $30 \pm 2{ }^{\circ} \mathrm{C}, 65 \pm 5 \mathrm{RH}$ and 13:11(L: D) photoperiod. The data were recorded as previously mentioned.

\section{Statistical analysis}

The mortality data were corrected using the formula of Abbott (1925), and subjected to probit analysis based on Finney (1971). Failure of $95 \%$ confidence limits to overlap at a particular lethal concentration indicated a 
significant difference. SPSS 16.0 Software for Windows was used to determine the correlation and multiple regression coefficients between the weather factors and the mean population of $P$. solenopsis.

\section{RERSULTS AND DISCUSSION}

\section{Population dynamic of $\boldsymbol{P}$. solenopsis}

During the season 2015, the infestation of $P$. solenopsis on cotton plants started at low density $(2.4 \pm$ 0.6 insects per twig) on June $14^{\text {th }}$ (Table 1). The population increased gradually and its highest peak $(142.9 \pm 15.6$ insects per twig) was observed on September $6^{\text {th }}$. During 2016, the first incidence of $P$. solenopsis was recorded on June $5^{\text {th }}(0.6 \pm 0.2$ insects per twig). The highest population density $(191.5 \pm 18.1$ insects per twig) was noticed on September $11^{\mathrm{th}}$. The population averages were $54.8 \pm 9.7$ and $70.5 \pm 13.6$ insects per twig in 2015 and 2016, respectively. It was observed that the petioles and among sepals of the flower buds and the terminal bud were the first infested parts of the cotton plant with $P$. solenopsis, which later spread over the entire plant. Also, in both seasons the infestation started when the cotton plants aged about two months, with the first formation of the flower buds. The present results are in parallel with Sahito et al. (2011) who observed the highest infestation of $P$. solenopsis on cotton during September and October, while Shahid et al. (2012) recorded the peak of the mealybug population in August and September, when the temperature ranged from $28-30{ }^{\circ} \mathrm{C}$. The highest $P$. solenopsis population $(222.3 \pm 22.8$ insects per cotton twig) was observed during the second half of September (Shah et al., 2015)

The population of $P$. solenopsis was significantly and positively correlated (Table 2) with the maximum (r $=0.77$ and 0.69$)$ and minimum $(\mathrm{r}=0.71$ and 0.67$)$ temperatures in 2015 and 2016, respectively. The correlation between the relative humidity and the population was positive and insignificant in 2015 and 2016 with $\mathrm{r}$ values of 0.33 and 0.49 , respectively. The multiple regression analysis revealed that the increase in the maximum temperature by $1^{\circ} \mathrm{C}$ increased the $P$. solenopsis population by 14.87 and 12.38 insects per twig in 2015 and 2016, respectively (Table 2). Similarly, $1^{\circ} \mathrm{C}$ increase in the minimum temperature caused an increase in the insect population by 4.02 and 3.76 insects per twig in 2015 and 2016, respectively. An increase in the relative humidity by $1 \%$ resulted in increasing of 3.22 and 3.94 insects per twig in 2015 and 2016, respectively. The development duration of $P$. solenopsis decreased as the temperature increased from 18 to $32^{\circ} \mathrm{C}$ (Prasad et al., 2012). Hanchinal et al. (2010) recorded a positive and significant correlation between the mealybug population and the maximum temperature with $\mathrm{r}$ value of 0.78 . Also, the infestation of $P$. solenopsis on cotton was positively correlated with the maximum and minimum temperature (Babu and Meghwal, 2014), and showed a positive correlation with the relative humidity with $\mathrm{r}$ value range of $0.23-0.76$ (Hameed et al., 2014).

According to the coefficient of determination values $\left(\mathrm{R}^{2}\right)$ of this study, the maximum and minimum temperatures and the relative humidity were responsible for the change in the population density of $P$. solenopsis by 63.7 and $54.2 \%$ during 2015 and 2016, respectively. The obtained results of correlation and regression analysis clearly showed that weather factors play important role in the development of $P$. solenopsis population.

\section{Susceptibility of $P$. solenopsis to some insecticides under laboratory conditions}

The results presented in Table (3) indicated that thiamethoxam proved to be the most effective insecticide $\left(\mathrm{LC}_{50}=23.6 \mathrm{mg} \mathrm{AI} \mathrm{L}{ }^{-1}\right)$ against the third instar nymphs of $P$. solenopsis using the leaf-dip method. Methomyl, acetamiprid and imidacloprid showed insignificant differences among them, recording $\mathrm{LC}_{50}$ values of $34.3,39.0$ and $43.5 \mathrm{mg} \mathrm{AI} \mathrm{L} \mathrm{L}^{-1}$, respectively. Based on the $95 \%$ confidence limits overlap, the $\mathrm{LC}_{50}$ values of chlorpyrifos (73.4 $\left.\mathrm{mg} \mathrm{AI} \mathrm{L}^{-1}\right)$ and deltamethrin $\left(94.8 \mathrm{mg} \mathrm{AI} \mathrm{L}^{-1}\right)$ were not significantly different from each other. The chitin synthesis inhibitor (lufenuron) was the least toxic with $\mathrm{LC}_{50}$ value of $556.1 \mathrm{mg} \mathrm{AI} \mathrm{L}{ }^{-1}$. The susceptibility of the third instar nymphs of $P$. solenopsis to the tested insecticides varied when the insect-spray method was adopted (Table 4). The $\mathrm{LC}_{50}$ values of acetamiprid, thiamethoxam, imidacloprid, methomyl and chlorpyrifos increased to be 56.5, 59.3, 66.4, 112.8 and $295.9 \mathrm{mg} \mathrm{AI}$ $\mathrm{L}^{-1}$, respectively. On the contrary, the $\mathrm{LC}_{50}$ values of deltamethrin (39.6 mg AI L $\left.{ }^{-1}\right)$ and lufenuron $(397.9 \mathrm{mg}$ $\mathrm{AI} \mathrm{L}^{-1}$ ) declined comparing to that obtained in the leafdip method.

These results indicated that the systemic insecticides: thiamethoxam, imidacloprid, acetamiprid and methomyl may have the ability to penetrate the cotton leaf tissue in the leaf-dip method resulting in their high toxic action compared to the non-systemic tested insecticides. The increased toxicity of deltamethrin and lufenuron in the insect- spray method comparing to that in leaf-dip method, may be attributed to their high molecular weights (505.2 and 511.2, respectively) and high solubility in lipids (Tomlin, 2003), which allow them to pass through the waxy secretions of the insect. Thiamethoxam, imidacloprid, methomyl and chlorpyrifos have been reported as effective insecticides against the cotton mealybug (Aheer et al., 2009; Suresh et al., 2010; El-Zahi et al., 2016). 


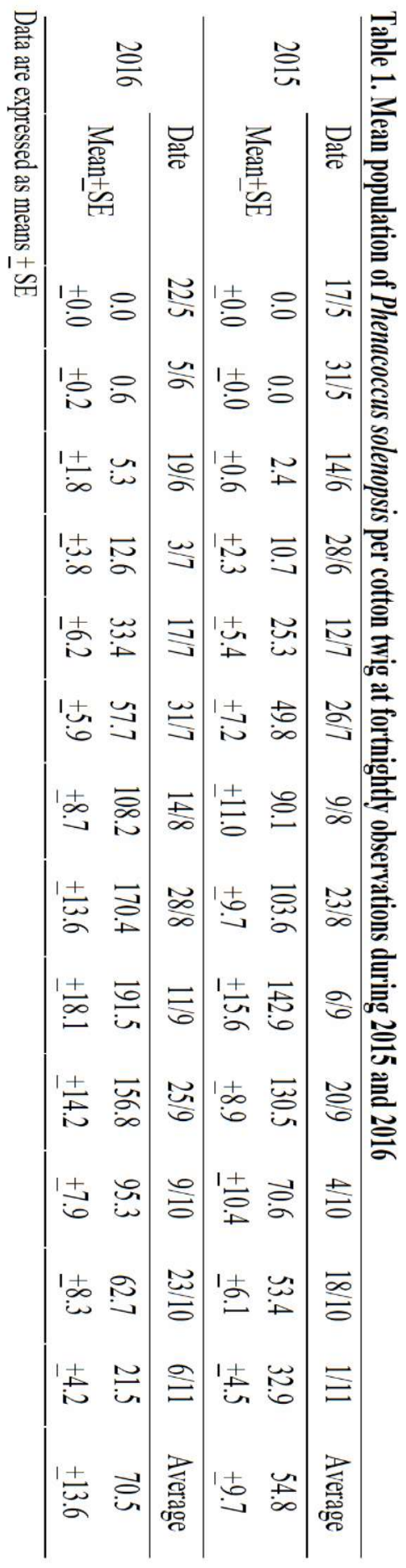


Table 2. Correlation (r) and multiple regression (b) coefficients between some weather factors and mean population of Phenacoccus solenopsis per cotton twig during 2015 and 2016

\begin{tabular}{|c|c|c|c|c|c|c|c|}
\hline \multirow[t]{2}{*}{ Season } & \multicolumn{2}{|c|}{$\begin{array}{c}\text { Maximum } \\
\text { temperature }\left({ }^{0} \mathrm{C}\right)\end{array}$} & \multicolumn{2}{|c|}{$\begin{array}{c}\text { Minimum } \\
\text { temperature }\left({ }^{\circ} \mathrm{C}\right)\end{array}$} & \multicolumn{2}{|c|}{ Relative humidity } & \multirow[t]{2}{*}{$\% \mathbf{R}$} \\
\hline & $\mathbf{r}$ & $\mathbf{b}$ & $\mathbf{r}$ & $\mathbf{b}$ & $\mathbf{r}$ & b & \\
\hline 2015 & $0.77 * *$ & 14.87 & $0.71 * *$ & 4.02 & $0.33^{\mathrm{NS}}$ & 3.22 & 63.7 \\
\hline 2016 & $0.69 * *$ & 12.38 & $0.67 *$ & 3.76 & $0.49^{\mathrm{NS}}$ & 3.94 & 54.2 \\
\hline
\end{tabular}

** Highly significant, $\mathrm{P} \leq 0.01-{ }^{*}$ Significant, $\mathrm{P} \leq 0.05-{ }^{\mathrm{NS}}$ Not significant.

Table 3. Susceptibility of Phenacoccus solenopsis third instar nymphs to some insecticides using leaf-dip method under laboratory conditions

\begin{tabular}{|c|c|c|c|c|}
\hline Insecticide & $\begin{array}{c}\mathrm{LC}_{50}{ }^{\mathrm{a}} \\
95 \% \mathrm{CL}^{\mathrm{b}}\end{array}$ & $\begin{array}{c}\mathrm{LC}_{90}{ }^{\mathrm{a}} \\
95 \% \mathrm{CL} \\
\end{array}$ & Slope value & $\chi^{2}$ \\
\hline Chlorpyrifos & $\begin{array}{c}73.4 \\
59.0-98.5 \\
\end{array}$ & $\begin{array}{c}309.0 \\
157.5-432.6 \\
\end{array}$ & $1.46 \pm 0.27$ & 0.44 \\
\hline Methomyl & $\begin{array}{c}34.3 \\
29.4-40.2 \\
\end{array}$ & $\begin{array}{c}118.7 \\
86.4-154.2 \\
\end{array}$ & $2.38 \pm 0.35$ & 2.71 \\
\hline Deltamethrin & $\begin{array}{c}94.8 \\
81.3-113.7 \\
\end{array}$ & $\begin{array}{c}227.8 \\
194.3-309.8 \\
\end{array}$ & $3.15 \pm 0.44$ & 5.59 \\
\hline Imidacloprid & $\begin{array}{c}43.5 \\
30.4-58.5 \\
\end{array}$ & $\begin{array}{c}177.5 \\
138.3-241.4 \\
\end{array}$ & $1.62 \pm 0.36$ & 2.65 \\
\hline Thiamethoxam & $\begin{array}{c}23.6 \\
18.6-28.4\end{array}$ & $\begin{array}{c}59.5 \\
47.4-86.1\end{array}$ & $3.21 \pm 0.42$ & 0.32 \\
\hline Acetamiprid & $\begin{array}{c}39.0 \\
28.9-52.7\end{array}$ & $\begin{array}{c}130.3 \\
89.9-190.2\end{array}$ & $1.72 \pm 0.33$ & 3.62 \\
\hline Lufenuron & $\begin{array}{c}556.1 \\
401.8-734.1\end{array}$ & $\begin{array}{c}2391.2 \\
1673.8-3491.1\end{array}$ & $1.52 \pm 0.36$ & 2.96 \\
\hline
\end{tabular}

${ }^{\mathrm{a}} \mathrm{LC}_{50}$ and $\mathrm{LC}_{90}$ are expressed in $\mathrm{mg} \mathrm{AI} \mathrm{L}{ }^{-1}-{ }^{\mathrm{b}} 95 \%$ Confidence limits

Table 4. Susceptibility of Phenacoccus solenopsis third instar nymphs to some nsecticides using insect-spray method under laboratory conditions

\begin{tabular}{|c|c|c|c|c|}
\hline Insecticide & $\begin{array}{c}\mathrm{LC}_{50} \\
95 \% \mathrm{CL}^{\mathrm{b}}\end{array}$ & $\begin{array}{c}\mathrm{LC}_{90}^{\mathrm{a}} \\
95 \% \mathrm{CL}\end{array}$ & Slope value & $\chi^{2}$ \\
\hline Chlorpyrifos & $\begin{array}{c}295.9 \\
218.9-402.4\end{array}$ & $\begin{array}{c}1334.5 \\
1080.9-1848.4\end{array}$ & $1.34 \pm 0.32$ & 2.96 \\
\hline Methomyl & $\begin{array}{c}112.8 \\
78.5-158.1\end{array}$ & $\begin{array}{c}442.2 \\
322.8-588.1\end{array}$ & $1.04 \pm 0.33$ & 0.31 \\
\hline Deltamethrin & $\begin{array}{c}39.6 \\
22.3-62.7\end{array}$ & $\begin{array}{c}130.7 \\
105.8-185.6\end{array}$ & $1.69 \pm 0.42$ & 3.26 \\
\hline Imidacloprid & $\begin{array}{c}66.4 \\
50.1-87.6\end{array}$ & $\begin{array}{c}278.8 \\
209.1-368.0\end{array}$ & $1.91 \pm 0.39$ & 0.25 \\
\hline Thiamethoxam & $\begin{array}{c}59.3 \\
43.7-79.5\end{array}$ & $\begin{array}{c}193.5 \\
127.8-278.6\end{array}$ & $2.51 \pm 0.57$ & 2.66 \\
\hline Acetamiprid & $\begin{array}{c}56.5 \\
43.8-69.5 \\
\end{array}$ & $\begin{array}{c}183.9 \\
132.7-305.3\end{array}$ & $2.50 \pm 0.45$ & 1.43 \\
\hline Lufenuron & $\begin{array}{c}397.9 \\
297.0-557.1\end{array}$ & $\begin{array}{c}1683.1 \\
1279.2-2810.7\end{array}$ & $1.73 \pm 0.35$ & 2.67 \\
\hline
\end{tabular}

${ }^{\mathrm{a}} \mathrm{LC}_{50}$ and $\mathrm{LC}_{90}$ are expressed in $\mathrm{mg} \mathrm{AI} \mathrm{L} \mathrm{Al}^{-1}{ }^{\mathrm{b}} 95 \%$ Confidence limits

Under laboratory conditions, Kumar et al. (2012) found that chlorpyrifos at $8 \mathrm{ml} \mathrm{L}^{-1}$ caused $61.3 \%$ mortality in the five days-old nymphs of $P$. solenopsis. The field rates of thiamethoxam and imidacloprid applied in the laboratory resulted in 95.2 and $81.6 \%$ mortality, respectively in the $2^{\text {nd }}$ instar nymphs of $P$. solenopsis
(Rashid et al., 2011). The results of the present study suggest that the complete coverage of treated plants in the case of systemic insecticides, and direct spray on the insects in the case of deltamethrin and lufenuron could be recommended to obtain a successful $P$. solenopsis control on cotton. 


\section{ACKNOWLEDGEMENTS}

The authors are thankful to professor El-Sayed Amer Gazia for the statistical analysis of the field experiments data.

\section{REFERENCES}

Abbas,G., M.J.Arif, M.Ashfaq, M.Aslam, S.Saeed. 2010. Host plants distribution and overwintering of cotton mealybug (Phenacoccus solenopsis; Hemiptera: Pseudococcidae) International Journal of Agriculture \& Biology 12 (3): 421-425.

Abbott,W.S. 1925. A method of computing the effectiveness of an insecticide. Journal of Economic Entomology 18: 265-267.

Aheer,G.M., R.Ahmad, A.Ali 2009. Efficacy of different insecticides against cotton mealybug, Phenacoccus solani Ferris. Journal of Agricultural Research 47 (1): 47-52.

Arif, M.I., M.Rafiq, S.Wazir, N.Mehmood, A.Ghaffar. 2012. Studies on cotton mealybug, Phenacoccus solenopsis (Pseudococcidae: Homoptera) and its natural enemies in Punjab, Pakistan. International Journal of Agriculture \& Biology 14 (4): 557-562.

Babu, S.R., M.L.Meghwal. 2014. Population dynamics and monitoring of sucking pests and bollworms on BT cotton in humid zone of Southern Rajasthan. The Bioscan 9 (2): 629-632.

Cudjoe, A.R., P.Neuenschwander, M.J.W.Copland. 1993. Interference by ants in biological control of the cassava mealybug, Phenacoccus manihoti (Hemiptera: Pseudococcidae) in Ghana. Bulletin of Entomological Research 83 (1): 15-22.

Dhawan, A.K., K.Singh, S.Saini, B.Mohindru, A.Kaur, G.Singh, S.Singh. 2007. Incidence and damage potential of mealybug, Phenacoccus solenopsis Tinsley on cotton in Punjab. Indian Journal of Ecology 34: 166-172.

El- Zahi, E.S.,S. A.Aref, S.K.M. Korish. 2016. The cotton mealybug, Phenacoccus solenopsis Tinsley (Hemiptera: Pseudococcidae) as a new menace to cotton in Egypt and its chemical control. Journal of Plant Protection Research 56 (2): 111-115.

Finney, D.J. 1971. Probit analysis ( ${ }^{\text {rd }}$ Ed.) Cambridge University Press, Cambridge, UK, p. 333.

Fuchs, T. W., J.W.Stewart, R.Minzenmayer, M.Rose. 1991. First record of Phenacoccus solenopsis Tinsley in cultivated cotton in the United States. Southwestern Entomologist 16 (3): 215-221.

Hameed, A., M. A.Aziz, G. M.Aheer 2012. Impact of ecological conditions on biology of cotton mealybug, Phenacoccus solenopsis (Hemiptera: Pseudococcidae) in laboratory. Pakistan Journal of Zoology 44 (3): 685-690.
Hameed, A., M.S.Shahzad, A.Mehmood, S.Ahmad, N.Islam. 2014. Forecasting and modeling of sucking insect complex of cotton under agro-ecosystem of MultanPunjab, Pakistan. Pakistan Journal of Agricultural Sciences 51 (4): 997-1003.

Hanchinal, S.G., B.V.Patil, M.Bheemanna, A.C. Hosamani. 2010. Population dynamic of mealybug, Phenacoccus solenopsis Tinsley and its natural enemies on BT cotton. Karnataka Journal of Agricultural Sciences 23 (1): 137139.

Kumar,R., M.Nitharwal, R.Chauhan, V.Pal, K.R.Kranthi. 2012. Evaluation of ecofriendly control methods for management of mealybug, Phenacoccus solenopsis Tinsley in cotton. Journal of Entomology 9 (1): 32-40.

Prasad, Y. G., M.Prabhakar, G.Sreedevi, G. R.Rao, B.Venkateswarlu. 2012. Effect of temperature on development, survival and reproduction of the mealybug, Phenacoccus solenopsis Tinsley (Hemiptera: Pseudococcidae) on cotton. Crop Protection 39 (9): 81-88.

Prishanthini, M., M.Vinobaba. 2013. Life cycle of the cotton mealybug Phenacoccus solenopsis in shoe flower plants under the laboratory conditions. Proceedings of the Third International Symposium, Seusl: 6-7 July, Oluvil, Sri Lanka. P. 57-62.

Rashid, M., M.K.Khattak, K.Abdullah, S.Hussain. 2011. Toxic and residual activities of selected insecticides and neem oil against cotton mealybug, Phenacoccus solenopsis Tinsley (Sternorrhyncha: Pseudococcidae) under laboratory and field conditions. Pakistan Entomologist 33 (2): 151-155.

Sahito, H.A., G.H.Abro, R.Mahmood, A.Q.Malik. 2011 Survey of mealybug, Phenacoccus solenopsis (Tinsley) and effect of bio-ecological factors on its population in different ecological zones of Sindh. Pakistan Journal of Agriculture, Agricultural Engineering and Veterinary Sciences 27 (1): 51-65.

Shah, T.N., A.M.Ahmed, N.Memon. 2015. Population dynamics of cotton mealybug, Phenacoccus solenopsis Tinsley in three talukas of district Sanghar (Sindh). Journal of Entomology and Zoology Studies 3 (5): 162167.

Shahid, M.R., J.Farooq, A.Mahmood, F.Ilahi, M.Riaz, A.Shakeel, I.V.Petrescu- Mag, A.Farooq. 2012. Seasonal occurrence of sucking insect pest in cotton ecosystem of Punjab, Pakistan. Advances in Agriculture \& Botanics 4 (1): 26-30.

Suresh, S., R.Jothimani, P.Sivasubrmanian, P.Karuppuchamy, R.Samiyappan, E.I. Jonathan. 2010. Invasive mealybugs of Tamil Nadu and their management. Karnataka Journal of Agricultural Sciences 23(1): 6-9.

Tomlin, C.D.S. 2003. The Pesticide Manual. $13^{\text {th }}$ Edition, British Crop Protection Council, UK. 


\section{الملخص العربي}

\section{ديناميكية تعداد بث القطن الاقيقي Phenacoccus solenopsis Tinsley على نباتات القطن والعلاقة بين حساسيته لبعض المبيدات وطريقة التعرض \\ الزاهي صابر الز اهي، عبد السلام إسماعيل فرج}

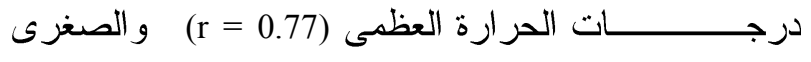

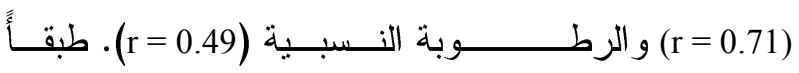

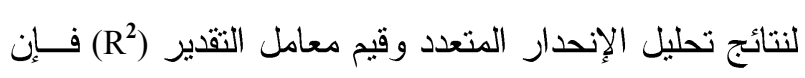
يرجات الحر ارة العظمى و الــصغرى و الرطوبــــة النـسبية مجتمعة تتحكم في التغبر فى تعداد بق القطن الدقيقي بنسبة

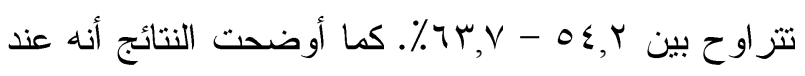

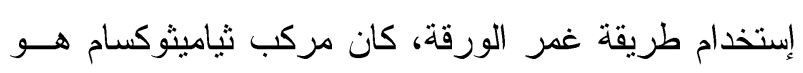

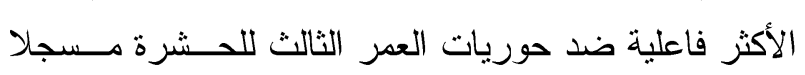

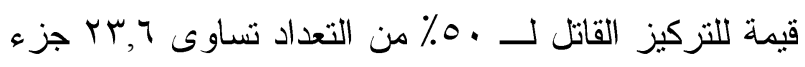

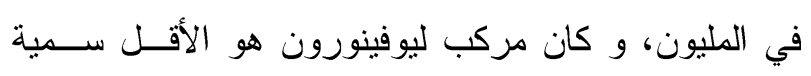

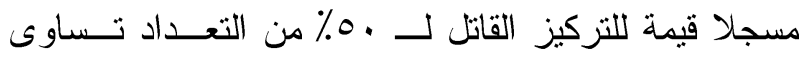
1,007 جزء في المليون. من ناحية أخرى أوضحت النتائج

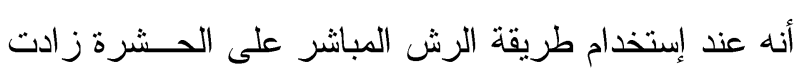

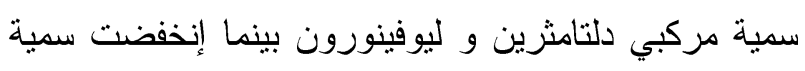
المركبات الباقية مقارنة بطريقة غمر الورقة.

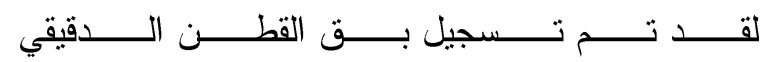
Phenacoccus solenopsis Tinsley (Hemiptera: لأول مرة كآفة جديدة على القطـن فــــ Pseudococcidae)

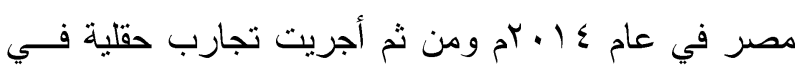

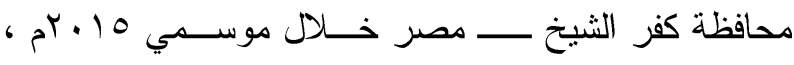

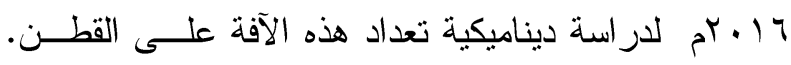

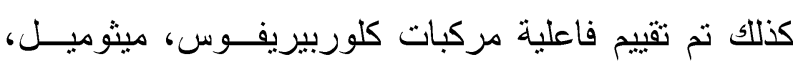

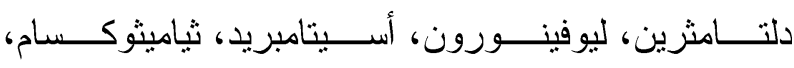

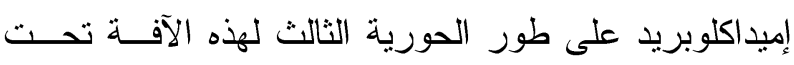

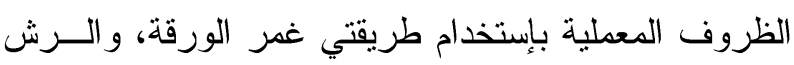

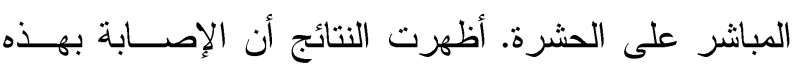
الحشرة بدأت مبكر ا فى شهر يونيه في كلا موسمى الدراسة التها عندما كان عمر نباتات القطن حو الي شهرين. سجلت أعلى بونى كثافة تعــداد للآفــه 11

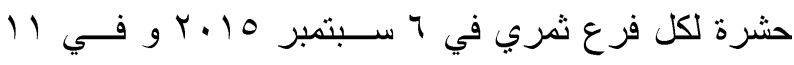

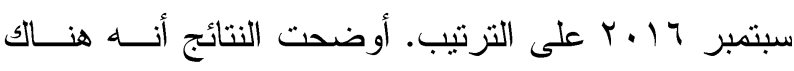

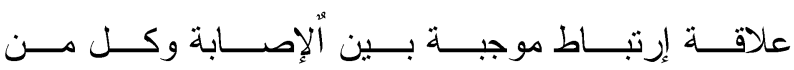

